\title{
THE COLONIAL 'OTHER' IN THE NINETEENTH CENTURY GERMAN COLONISATION OF AFRICA, AND INTERNATIONAL LAW
}

\section{Mohammad Shahabuddin*}

\section{Introduction}

Conceiving the ethnic 'other' as backward and primitive by the dominant cultural group of each epoch is a norm of international relations that dates back to antiquity. Ancient Greece considered nonGreeks as 'barbarians', and firmly believed that these barbarians were born enemies designated by nature to serve the Greeks as slaves. Whereas Greek States held a strong feeling of 'all-Greek kinship' for one another - a feeling that they belonged to the same racial, cultural, lingual and religious community - despite their political segregation and discord. ${ }^{1}$ Other regional systems too approached international relations through the same dichotomous understanding of 'self' and 'other'. 2

I am thankful to Professor Matthew Craven (SOAS, University of London), Professor David Kennedy (Harvard Law School), Professor Antony Anghie (University of Utah), and Professor YasuakiOnuma (University of Tokyo) for their insightful comments on the draft article.

The author holds a $\mathrm{PhD}$ in international law (London). He is currently the Chairman of the Department of Law \& Justice at Jahangirnagar University in Bangladesh.

1 See Arthur Nussbaum, A Concise History of the Law of Nations (NY: Macmillan, 1947), 11.

2 In the interaction between the Christian Europe and the Muslim Orient, the latter too relied on its religious norms in inter-State relations. Thus, though citizens and diplomats of the Italian City States were granted concessions by Oriental rulers in the familiar form of franchises or diplomas, Muslim rulers were little interested in obtaining for their subjects reciprocal treatment in the respective 
Thus, irrespective of the origin of international law or to put it more correctly, the debate about the origin of international law, it is evident that the body of rules governing international relations had been informed by notions of superior 'self' and inferior ethnic 'other'. Among different regional systems of international law in antiquity and the Middle Ages, which were limited in their application, modern European international law having its root in the sixteenth-century jurisprudence emerged as a universal norm of interstate relations through the nineteenth-century colonial expansions. ${ }^{3}$ Since then, it has become the dominant language of European civilisation; it is the

European countries, for they thought the Mohammedan law forbade the believers to sojourn for any length of time in the lands of the infidels. Similarly, nonMuslim settlers in Muslim States were allowed to preserve their own law given that "the Moslem law as set forth in the Koran was exclusively designed for the Moslem, who consequently did not care to regulate relations among infidels". See Nussbaum, A Concise History, 38-39. Likewise, the Sinocentric tribute system claimed ethnic superiority by depicting the 'other' around it as 'barbarian'. The fundamental philosophy underlying the tribute system under the Chinese Empire was the rule by virtue, i.e. the emperor should embody virtue and spread it throughout under Heaven. Under this belief system, the rulers beyond the immediate influence of Chinese civilisation, i.e. non-East Asians, must also obey the Emperor - the only supreme authority under Heaven. As a general rule, even uncivilised people were expected to understand the virtue of the Emperor, and send a tributary mission to the emperor in order to share in his virtuous rule. See generally YasuakiOnuma, "When Was the Law of International Society Born?" Journal of the History of International Law 2 (2000), 12-22.

3 Tracing the necessity of international law in the face of the eruption of independent States in Europe, Oppenheim saw the emergence of this discipline in the seventeenth century; thus, he had no hesitation to enthusiastically recognise the Dutch diplomat Hugo Grotius as the "Father of Law of Nations," for the "system of Grotius supplied a legal basis to most of those international relations which were at the time considered as wanting such basis." See, Lassa Oppenheim, International Law (London: Longmans, Green and Co., 1905), 58. This claim is not beyond controversy, however. Some influential publicists after the end of the nineteenth century, such as James Brown Scott, argued that those of the late Spanish school such as Francisco de Vitoria were the true founders of international law, while there were others who emphasised the importance of Vattel, pointing out modern, liberal features in his writing. See, Onuma, 5. See also AntonyAnghie, "Finding the Peripheries: Sovereignty and Colonialism in Nineteenth-Century International Law," Harvard International Law Journal 40 (1999) 1, 1-80. 
European 'self' that defines and deals with the non-European 'other' through international law, amongst other means.

Yet, within this dichotomy of the European 'self' and the nonEuropean 'other', we can observe how the nineteenth-century European discourse on national self-images, within the framework of the liberal and conservative traditions, are reflected in the conception of the non-European 'other', and hence in corresponding policies dealing with the latter. This is best substantiated by the nineteenthcentury colonial projects. On the one hand, the justifications for colonial missions were expressed in light of the concept of the 'nation' in the metropolis along the lines of liberal or conservative traditions. On the other hand, the same traditions explained the science of race - social Darwinism - in the parallel monogenic-assimilationist or polygenic-exclusionist streams ${ }^{4}$ to inform the hierarchical relationship between the Europeans and the natives in the colonies. During this period of empire building, as we shall soon see, the nineteenth-century jurists of both traditions, not only justified the colonial project, but also the atrocities associated with it.

This article examines the colonial policy of nineteenth-century Germany to explore how its conservative treatment of ethnicity, in relation to the construction of the national 'self,' distinctively informed its understanding of colonialism as well as the actual execution of their colonial policies. To this end, I first offer an account of the nineteenth century German perception of 'ethnicity' as the core of the political organization of nation-states - the self-image of the

4 Dickens notes that in the $1860 \mathrm{~s}$, there was intense debate in Britain between the monogenists, who argued that there was a common ancestor for all human races, and the polygenists, who held the view that different races are indeed separate species. See Peter Dickens, Social Darwinism (Buckhingham: Open University Press, 2000), 14. For an account of social Darwinism, see M. Hawkins, Social Darwinism in European and American Thought, 1860-1945 (1997), 61-122; P. Dickens, Social Darwinism (2000), 7-25. Referring to Herbert Spencer as the pioneer of social Darwinism, Greene argues that the historical context of Darwin's work in particular and the interaction between science and society in general tend to emphasise the links between Darwin and Spencer consisting of a network of shared assumptions and viewpoints about God, Nature, society and history, which rendered Spencer a 'Darwinian before Darwin'. See J.C. Greene, Science, Ideology and World View (1981), 134, 140. For a Spencerian account of social evolution, see generally J.D.Y. Peel (ed), Herbert Spencer on Social Evolution-selected writings (1972). 
nation vis-à-vis the 'other'. Against this backdrop, my account of the German colonial project exposes how the interaction with the colonial 'other' was reflected back in the dynamic process of the construction of the 'self' in the metropolis. While providing this narrative, I demonstrate how nineteenth-century international lawyers' perceptions of the State - the legal form of the national 'self' - in the conservative tradition was essentially reflected in their justifications for colonialism.

\section{The Meaning of 'Ethnicity' in the German Romantic Tradition}

In the nineteenth century, the idea of 'culture' dominated the quest for constructing the self-image of a nation. This quest appears, in Gellner's account, largely as the Romantic response to the Enlightenment. The Enlightenment was premised on the "individualistic, universalistic and egalitarian" ethic as opposed to the "oppression, dogmatisation, superstition and inequality of the agrarian age." The Romantic response to the Enlightenment had its root in the German tradition. To the Germans, the authentic Kultur of the German people was to be preferred to the French notion of rational, scientific and universal civilisation - the Enlightenment. ${ }^{6}$ The eighteenthcentury German philosopher Johann Herder is one of the key proponents of this emergent Romantic nationalism who, despite acknowledging that all mankind shared the same basic attributes, claims that nations have modified their characters according to their specific cultural condition. ${ }^{7}$ The link to the specificity is so strong that Herder sees all the aspects of the population within a nation - the constitution of their body, their way of life, the pleasures and occupations to which they have been accustomed from their infancy,

5 Ernest Gellner, Nationalism (London: Weidenfeld\& Nicolson, 1997), 64. See also Ernest Gellner, Nations and Nationalism (Oxford: Basil Blackwell, 1983); E. Gellner, Culture, Identity, and Politics (Cambridge: Cambridge University Press, 1987).

6 Adam Kuper, Culture (Cambridge, MA: Harvard University Press, 1999), 6-9.

7 Johann Gottfried von Herder, "Reflections on the Philosophy of the History of Mankind (1791)," inOmar Dahbour and Micheline R Ishay (eds.),The Nationalism Reader (New Jersey: Humanities Press, 1995), 48-57. 
to the whole circle of their ideas - as climatic. ${ }^{8}$ And then he concludes: "Deprive them of their country, you deprive them of everything." 9 For him, the nation is like an enlarged family, and the most natural State is one which is composed of a specific people with a unique national character. ${ }^{10}$ It is, therefore, opposed to the verdict of nature, he argues, to expand the nation beyond its natural limits and thereby cause the indiscriminate mingling of various nations and human types. ${ }^{11}$ A nation, in the Herderian sense, is thus a unique and specific ethnic connotation.

Like Herder, the German political theorist Johanne Fichte, too inclined to the uniqueness of the German Kultur, despite his strong faith in the universal solidarity enshrined in the French Revolution. This shift from liberal universalism to the locality of culture was caused by the increasing French expansionism, under the pretext of liberalism at the dawn of the nineteenth century. ${ }^{12}$ His perception of the international order and international law in the face of expansionism, thus, begins from the idea of mutual recognition of nations as well as mutual guarantees of security. ${ }^{13}$ His late works clearly reveal this shift from liberalism to Romanticism. In his celebrated work, Address to the German Nation (1808), less than a decade before he died, he portrays the German nation as an authentic entity with all its peculiar natural characteristics. The original and truly natural frontier of all States, he asserts, are undoubtedly their inner frontiers, in that

"[t]hose who speak the same language are linked together, before human intervention takes a hand, by mere nature with a host of invisible ties; they understand each other and are capable of communicating more, and more

\footnotetext{
$8 \quad$ Ibid., 51.

9 Ibid.

10 Johann Gottfried von Herder, "Ideas towards a Philosophy of the History of Mankind (1785)," in Alfred Zimmern (ed.), Modern Political Doctrines (London: Oxford University Press, 1939), 165.

11 Ibid.

12 SeeJohanne Gottlieb Fichte, "An Outline of International and Cosmopolitan Law (1796-97)," in H.S. Reiss and P. Brown (eds.), The Political Thought of the German Romantics(Oxford: Basil Blackwell, 1955), 73-84.

13

Ibid., 75.
} 
closely with one another, they belong together, they are by nature one indivisible whole." 14

These features are so peculiar to that particular nation that any nation of a different origin and language that would try to appropriate and absorb such a people could do this only by confusing itself as well as profoundly disturbing the uniform progress of its own education. ${ }^{15}$ Fichte then concludes that only such a culturally specific inner frontier, drawn by the spiritual nature of man, "first gives rise to outward frontiers of territories as a direct consequence."16 Accordingly, he saw Germany as a culturally and linguistically unified entity, sufficiently distinct from all other nations, and located at the centre of Europe as a 'dividing wall' between the unrelated tribes surrounding this great nation. ${ }^{17}$

Within this Romantic framework, no doubt, Fichte found the idea of universalism quite problematic; to take his words, 'despicable' and 'irrational' ${ }^{18} \mathrm{He}$ contends that the phenomenon of divinity reflects on a nation only when each nation develops and takes shapes in accordance with its own peculiarities; it is this peculiarity that guarantees the present and future dignity, virtue and merit of nations. In contrast, he warns, "if these qualities are dulled by mixture and disintegration there arises from this lack of peculiarity a separation from spiritual nature, and from this there arises the fusion of all in uniform and conjoint ruin". ${ }^{19}$ Thus, his vision of the world comprises culturally specific nations.

Compared to Herder and Fichte, the nineteenth-century scholars of German Historical School, such as Leopold Ranke, took a more conservative stance. For Ranke, the greatness of a nation lies not in the extent of possessions or the power of the troops or the amount of wealth or a certain share in the general civilisation, but in the moral strength of a nation and the sense of nationality - the two most

14 Johanne Gottlieb Fichte, "Addresses to the German Nation - Thirteenth Address (1808)," in The Political Thought of the German Romantics, 102.

15 Ibid.

16 Ibid., 102-103.

17 Ibid., 103.

18 Ibid., 108.

19 Ibid. 
important elements but for which a State cannot exist. ${ }^{20}$ In the face of ever-increasing influence of the French philosophy of rationality and materialism, Ranke advocated for a counter-spiritual force nationalism - to contain that influence: "The dominion which another nation threatens to gain over us can only be combated by developing our own sense of nationality." 21 And while explaining this nationalist spirit, he actually refers to "the real, existing one" - not merely an invented, illusionary nationality - which is expressed in the State. ${ }^{22}$ It implies, therefore, that the authentic root of the German nation-State needs to be traced; nothing could be a better tool to this end than the idea of 'race'.

\section{The Ethnic Background of German Colonialism}

The nineteenth-century German idea of the 'self' - the ethnic nation - informed its relationship with colonies - the 'other' - in a number of ways. Although colonial proposals were discussed in the Frankfurt National Assembly in 1848, no major interest groups supported colonial expansion. The State governments, namely, Prussia, Hamburg, and Bremen, which were most in a position to effect a colonial policy, were against the idea of colonisation. ${ }^{23}$ However, a majority of western German liberals remained an exception to this general trend. As a matter of fact, the liberals advocated colonial policy back in 1848 in the face of massive German emigration from the south-western Germany, which intensified with the growth of industrialisation and ensuing socio-economic changes. The German over population, especially in rural areas, was also said to have boosted emigration. ${ }^{24}$ During the period between 1830 and

20 Leopold von Ranke, “The Great Powers (1833)," inDahbour and Ishay (eds.),The Nationalism Reader, 158.

21 Ibid., 159.

22 Ibid.

23 Woodruff D Smith, The German Colonial Empire (Chapel Hill: The University of North Carolina Press, 1978), 5.

24 However, Smith argues that seen from a more modern standpoint, "emigration was the product, not of absolute overpopulation, but of the development of German agriculture towards large-scale capitalist forms under severe economic pressure, compounded by a gradual reduction in the size of independent farms through their division among sons of farmers". See ibid., 10. 
1860, over one million Germans left for the United States; others went to Brazil and Chile. ${ }^{25}$ After 1895, an estimated 830,000 Germans emigrated from Prussia alone, making depopulation a great threat to German nationalism. ${ }^{26}$

Nevertheless, the liberals of 1848 , whose prominence in politics at that time was temporary, considered colonisation as a policy option in non-nationalist terms. Their concern was that lower-class people, who had been displaced by changes in German agriculture, would become criminals and possibly revolutionary; thus, colonies would be a good option for exporting those people. ${ }^{27}$ Despite the fact that Bismarck allowed his political allies to appeal to sentiment in favour of colonies in order to rally support for unification in western Germany, he himself remained publicly opposed to overseas colonies until the 1880s; based on the projected financial burdens of maintaining overseas colonies and the strategy of avoiding any serious confrontation with other major colonial powers. ${ }^{28}$ Therefore, it was not a surprise that most of Germany's colonial acquisitions took place quite late, between April 1884 and February 1885. ${ }^{29}$

25 Edward J.Neather, "Introduction to the English Edition," in JurgenZimmerer and Joachim Zeller (eds.), Genocide in German South-West Africa, trans. E.J. Neather (Monmouth: Merlin Press, 2008 [2003]), xix.

26 Mark Mazower, Hitler's Empire - Nazi Rule in Occupied Europe (London: Penguin Books, 2008), 21.

27 Smith, The German Colonial Empire, 4.

28 In a letter to the Minister for War, Bismarck wrote: "On the one hand the advantages for trade and industry of the motherland, which are expected from the possessions of colonies, for the most part are based on illusions. Because the costs caused by the establishment, support and maintenance of colonies, often exceed the benefit enjoyed by the motherland, as the experiences of England and France prove [...]. On the other hand our navy is not yet sufficiently developed to take responsibility for the protection in distant states. Finally, the attempt to found colonies in regions claimed by other states, no matter if with or without legitimation, would cause manifold, undesired conflicts." See Hans Spellmeyer, Deutsche Kolonialpolitikim Reichstag (Stuttgart, 1931), 3, cited in Neather, "Introduction to the English Edition," in Genocide in German South-West Africa, xxii.

29 This timeline categorically applies to African colonies of South West Africa (April 1884), Togo (July 4-6, 1884), Cameron (July 14, 1884), and East Africa (February 1885). However, the official acquisition of colonies in the pacific and in China took place in 1899 and 1888, respectively. See Elise von JoedenForgey, Nobody's People: Colonial Subjects, Race Power and the German State, 1884-1945, PhD dissertation, University of Pennsylvania, 2004, ch. 1, fn. 1, 52. 
However, German ethnic nationalism soon emerged as a uniquely dominant factor in German politics in the discourse on the viability of colonial projects. German unification, its appearance as a Great Power in the middle of Europe, and intense international economic competition enhanced by the depression of 1873 - all contributed to an increased support for Germany's participation in the colonial mission. While the depression simultaneously provided the German middle-class, who had to swallow the worst of it, with a fresh impetus for further emigration jeopardising the vision of a unified, ethnic German nation. ${ }^{30}$ The urge for protecting German culture by preventing de-Germanisation put the idea of emigrationist colonialism in a nationalist light that would conveniently reconcile both the needs of emigration and the protection of culture. In the words of Smith:

Freedom to emigrate if conditions should become too unbearable was widely accepted as the ultimate recourse of the lower orders of respectable society, and parties (...) that emphasised continued freedom of emigration were supported by these groups. The same group also tended to support emigrationist colonialism, since colonies offered an alternative to normal emigration that preserved both the German culture of the emigrants and their contributions to the German economy. Especially after 1871 and the growth of lower-middle-class nationalism, colonialism attained some popularity because it reconciled patriotism with freedom to desert Germany. ${ }^{31}$

Thus, the shift from a liberal vision of emigrationist colonialism to a more culturalist project accommodated nationalist passion. This also allowed Bismarck, who always kept alive his instrumental considerations for colonisation, to manoeuvre middle-class support for subjugating the left liberals from their electoral support in the $1870 \mathrm{~s}$ and $1880 \mathrm{~s} .{ }^{32}$

During the period 1879-1884, colonialist organisations played pivotal roles in popularising colonialism, and the intellectual figures behind the institutional campaign mostly put their arguments in ethnonationalist terms. For example, one of the foremost German colonial

\footnotetext{
30 At the same time, economic groups within Germany related their projected fortune to Germany's success in colonial affairs. See Smith, 7.

32 Ibid., 18.
} 
activists and missionaries, Friedrich Fabri, initially premised his arguments in favour of colonies on economic considerations favoured by big businesses. Later he claimed that the population overflow caused by the natural vigour of the German race could be directed to the colonies. ${ }^{33}$ With his nationalist passion, Fabri "demonstrated graphically and alarmingly how the constant loss of Fatherland of youth, talent, skill, business ability and initiative (for it is always the best who go), was constantly depleting Germany of her vitality". ${ }^{34}$ Thus, his argument followed that settlement colonies would not only accommodate German farmers and small bourgeois with an agricultural economy and a traditional middle-class society, but also save the emigrants' capabilities for Germany and would prevent their de-Germanisation. ${ }^{35}$

Another colonialist, Wilhelm Hubbe-Schleiden, shared Fabri's view of emigrationist colonialism in more aggressive terms. Despite his financial interests in a number of tropical trading concerns, his colonialist writings were devoted to downplaying the commercial and industrial sides of German life and emphasising the heroic, cultural, and agricultural aspects. ${ }^{36}$ For him, colonies were necessary to prevent the degeneration of the German people through industrialisation and the sapping of Germany's strength through emigration. This would, thereby, maintain German culture and prevent its decline, in contrast to the example of England, "where the typical person had become a crass material and a $\operatorname{cog}$ in an industrial machine". ${ }^{37}$ Depicting industry as a necessary evil that caused social and cultural damage, Hubbe-Schleiden found essentials of national 'health' and 'power', such as the human traits and social organisations, in the traditional agrarian economy. Thus, he envisaged that the 'heroic' German with

33 Friedrich Fabri, Bedarf Deutschland der Colonien? (Gotha, 1879), 1-13, 20-32, cited in ibid., 23.

34 Mary Evelyn Townsend, Origins of Modern German Colonialism, 1871-1885 (NY: Columbia University, 1921), 92.

35 Fabri, BedarfDeutschland der Colonien?1-13, 20-32, cited in Smith, 23.

36 Wilhelm Hubbe-Schleiden,

UberseeischePolitik, eineCulturwissenschaftlicheStudie (Hamburg, 1881), 13-14, 74-75, cited in Smith, 24. 
his agrarian culture would prosper in the colonies that would help Germany continue on its road to greatness and dominance. ${ }^{38}$

A similar approach to the colonial project was taken by Carl Peters, the most famous of all colonialists of that time, who despite his personal interest in overseas trading companies nonetheless took a nationalist stance while he advocated that Germans living in overpopulated Germany had to move somewhere. He argued further that if Germany were to retain the productive power of the emigrants and protect their culture, colonies were a necessity. ${ }^{39}$ Although Peters and his associates established colonial trading enterprises, Smith notes, their propaganda often endorsed as well as advanced the popular idea of large-scale agricultural settlements. ${ }^{40}$

Such a position on German colonialism was also taken by Heinrich von Treitschke, who conceived international relations essentially as self-interested arrangements outside the domain of law. He argued that "[f]or a nation that suffers from continual over-production, and sends yearly 200,000 of her children abroad, the question of colonisation is vital". ${ }^{41}$ Having predicted that the German emigration would continue for a long while to be an unavoidable necessity even if Prussia resumed the colonisation of its eastern borderlands, he proposed that it was a new duty for the motherland to ensure that her 'wandering children' remained true to their nationality, and simultaneously open new channels for her commerce. ${ }^{42}$ Thus, he concluded that Germany was justified on the ground of 'national self-preservation' to seek ways and means to divert the stream of German emigrants into lands where they would be able to maintain their nationality. ${ }^{43}$

Ibid., 25.

39 Carl Peters, GesammelteSchriften, ed. Walter Frank, 3 vols. (Munich, 1943), 1:332-341, cited in Smith, 26.

40 Carl Peters, ZurWeltpolitik (Berlin, 1912), 141-145, cited in Smith, 26. Smith notes that Peters is a difficult character to assess, who was genuinely interested in settlement colonies and German empowerment in world politics, but at the same time was quite keen to get his own share.

41 Adolf Hausrath, com and trans, Treitschke: His Doctrine of German Destiny and of International Relations Together with a Study of His Life and Work (NY: G.P. Putnam and Sons, 1914), 205.

Ibid., 209. 
However, although the nationalist agenda was at the forefront of colonial advocacy in the 1880s, a parallel stream of support from the German government and business interests in favour of colonial acquisition on non-nationalist grounds also emerged. Given the high degree of public support for nationalist notions of settlement colonies, protagonists of economic colonialism often relied on nationalist rhetoric to advance their own projects, while nationalists never dismantled the relevance of economic considerations for the viability of such a mega project of overseas settlement. ${ }^{44}$ Such moderate reconciliation offered Bismarck, who conceived of an ideal German colony in terms of the classic trading-colony model, the opportunity to manage domestic politics. As Smith notes:

"Bismarck's motives in acquiring colonies were complex and varied, but it appears from the available evidence that the basic impetus to expansion is to be found in domestic politics and Bismarck's attempt to manipulate them." ${ }^{~ 45}$

Nevertheless, with the strengthening of the conservative nationalist voice advanced by the Colonial Society and the Pan-German League after 1885, Bismarck was under increasingly high pressure to change his policy of trading colonialism. ${ }^{46}$

In this sense, the very notion of German colonialism is a product of a series of inter-connected factors - nationalism, large business interests, government's instrumentalist calculations, and domestic political dynamics - though often it appeared in the dichotomy of economic and settlement models of colonialism. But what we trace in particular is that nationalist elements, premised on middle-class support for initiating German settlements in colonies in order to protect German culture, remained a decisive force behind German colonial expansionism, which only gained strength with the passage of time, with Germany's march towards greater expansion until she faced sheer humiliation in successive world wars.

German international lawyers, Koskenniemi notes, started to write about colonialism only after Bismarck had changed his attitude towards colonisation in 1884 . But their response to the subject was

\footnotetext{
Smith, The German Colonial Empire, 27.

Ibid., 33.

46 Ibid., 44.
} 
based on municipal public law, instead of international law, in that they focused primarily on how German protectorates could be fitted into the imperial constitution. ${ }^{47}$ For them, colonisation was a natural part of Germany's development into a leading European power. For example, the writings of the early commentators on colonialism such as Paul Heilborn, Karl Heimburger, and Friedrich Geffcken all understood colonisation as an obvious, natural phenomenon; they engaged themselves merely in justifying Germany's right as a latecomer to the imperial venture, or in explaining the legal technicalities of the concepts of 'protectorate' and 'territorial sovereignty', for example. ${ }^{48}$ German jurist Heimburger maintained in 1888 that the State's quest for territory is a justified "expression of its life-energy" under international law, and is "protected as long as it does not conflict with the legal spheres of the other European States." 49 Such an approach of German international lawyers towards the colonial project essentially reflected their perception of the State as a racially superior organic body and its sovereign authority in absolute sense.

Thus, in the Theory of the State, Bluntschli argued that the settlement of political communities in an uninhabited and scarcely cultivated country, with the intention of founding a new State, is a peaceful form of territorial acquisition. And then he maintained that if the 'barbaric natives' remained in the territory of the new colony, the superiority of the 'civilised' over a barbarous people would necessarily lead to the dominion of the former. ${ }^{50}$ In another place, while talking about the superiority of the Aryans as a philosophical and rational race, he noted that the Aryan races were superior because they emphasised the dignity and honour of human beings, in contrast to the Africans, who "allowed his master to enslave him, even threw himself on the ground before his master, and lifted the master's foot

47 MarttiKoskenniemi, Gentle Civiliser of Nations: The Rise and Fall of International Law 1870-1960 (Cambridge: Cambridge University Press, 2002), 109.

48 Ibid.

49 Cited in ibid.

50 Johann KasparBluntschli, The Theory of the State (Ontario: Batoche Books, 2000 [1885]), 219. 
himself on his head." ${ }^{51}$ Of the Aryan races with unparalleled political excellence, Bluntschli continued, it was the Germanic people who flourished most in the elevation and clarity of ideas regarding the theory of States. His conclusion followed that the Aryans were under a great historical responsibility to educate other races in political theory and statehood. Further, to teach them "to develop and complete the domination of the world which already lies in the hands of the Aryan peoples in a consciously humanistic and noble way, so as to teach civilisation for the whole mankind." 52

This sense of Germanic racial superiority, Dampierre noted in German Imperialism and International Law, was offered a scientific basis by Darwinism. The evolutionary thoughts rationalised the imperialistic tendencies of intellectual Germanism not only by corroborating the idea of the inherent superiority of certain races, but also by scientifically justifying the elimination of the weak by the strong. ${ }^{53}$ It implied from this principle of unequal evolution that, among all the human races, it was the Germanic race that had undergone the most perfect evolution. Thus, German intellectuals believed that, seen from the point of view of Germany's aptitude for expansion as an organised community, it had reached "a stage of its evolution at which it was incumbent upon all the others to submit to its sovereignty." ${ }^{54}$ Treitschke's disciple Bernhardi, therefore, declared on the eve of the First World War that

[t]he struggle for existence is, in the life of Nature, the basis of all healthy development. All existing things show themselves to be the result of contesting forces. So in the life of man the struggle is not merely the destructive, but the life-giving principle. The law of the stronger holds good everywhere. Those forms survive which are able to procure themselves the

51 Johann KasparBluntschli, "Arische Volker und arischeRechte," in GesammelteKleineSchiften, 2 vols (Nordlinger: Beck, 1879), 74-77, cited in Koskenniemi, 103.

52 Quoted in Koskenniemi, 104.

53 Jacques Marquis de Dampierre, German Imperialism and International Law Based Upon German Authorities and the Archives of the French Government (NY: Charles Scribner's Sons, 1917), 32.

54 Ibid., 32-33. 
most favourable conditions of life, and to assert themselves in the universal economy of Nature. The weaker succumb. ${ }^{55}$

Bernhardi, thus, conceived of colonisation essentially as a matter of recognised right, for through colonisation "vast territories inhabited by uncivilised masses are occupied by more highly civilised States, and made subject to their rule. Higher civilisation and the correspondingly greater power are the foundations of the right to annexation." 56 Given that Germany was a late-comer in the imperial game and burdened with the surplus population which the mother-country could no longer feed, Bernhardi proposed that the only course left to Germany was to acquire the necessary territory by war: "Thus the instinct of selfpreservation leads inevitably to war, and the conquest of foreign soil. It is not the possessor, but the victor, who then has the right." $57 \mathrm{He}$ maintained further that since might is the supreme right, and the dispute as to what is right is decided by war, might confers the right to occupy or to conquer. War, according to him, was a biological determinant between just and unjust, for its decisions rested on the very nature of things. ${ }^{58}$

\section{The Projection of the Ethnic 'Self' on the Colonial 'Other' through Exclusion}

While the German notion of the ethnic 'self' constituted a major force behind the German colonial mission in the internal context, however, in the external context, i.e. in Germany's relationship with the colonial 'other', it demonstrated an inherently polygenic as well as exclusionist attitude towards the colonial 'other'. It is also to be noted from the outset, within the dichotomous colonial model of nationalistsettlement and instrumentalist-trading in German politics, Bismarck's inclination for the latter offered only South West Africa as a suitable

\footnotetext{
55 General Friedrich Von Bernhardi, Germany and the Next War, trans. Allen H Powels (NY: Chas A Eron, 1914), 18. 
venue for large-scale German settlement. ${ }^{59}$ South West Africa thus became the focal point of radical Rightists' nationalist campaign for German settlement. It also offered an opportunity retrospectively to explore how the German nation, juxtaposed with the African natives in order to protect its ethno-national 'self' in the face of massive emigration, simultaneously endeavoured to 'distance' itself from the natives. This had to happen, paradoxically, for protecting its racial superiority from any undesired racial inter-mixing. The exclusion of the 'other' in forms of strict racial segregation on polygenic grounds was the obvious policy option to that end.

Consequently, to combat the increasing number of marriages between whites and African women, ${ }^{60}$ the colonial government of South West Africa opted for legislation that would erect a significant barrier between natives and non-natives with a view to protecting "the ranks of Europeans against an influx of coloured blood."61 When Governor Tecklenburg banned mixed marriages in 1905 in defiance of directives of the Department of Colonial Affairs in Berlin, he evidently relied on racial, exclusionist logic against mixed marriages:

59 Although Togo was considered as the 'model colony', Rohrbach argues that it was so from merely economic point of view as a market and source of raw materials, for its tropical climate was not suitable for mass German settlement. See Paul Rohrbach, Der deutsche Gedanke in der Welt (Dusseldorf; Leipzig: 1912), 133-160, cited in Smith, 67. Similarly, in the case of Cameroon, the PanGerman League's approach contrasted a business-oriented colonial policy with a more patriotic settlement one. Foerster notes that given the absence of white agricultural population in Cameroon, Pan-German spokesmen sometimes supported a black peasantry as a substitute to industrialisation. See E.Th. Foerster, Das Konzessionsunwesen in den DeutschenSchutzgebieten (Berlin: 1903), 18, cited in Smith, 83. As a matter of fact, the Pan-German League continually attacked the government for its unwillingness to support settlement anywhere except Southwest Africa, and also for its concession-company policy along with the lack of vigorous efforts to expand the empire. See Smith, The German Colonial Empire, 144.

60 Although the white Europeans in most cases looked down upon the African women as racially subordinated, they maintained relationship with the latter due to lack of white women or the possibility of gaining economic benefits from the elite African family.

61 JurgenZimmerer, "The Model Colony? Racial Segregation, Forced Labour and Total Control in German South West Africa," in Genocide in German South West Africa, 19-21. 
Not only will the preservation of the purity of the German race and of German civilisation be very significantly harmed, but also, and above all, the authority of the white man will be endangered. [...] experience had long shown, and not only in Africa, that when a white person lives for an extended period with a number of a subordinate race, it is not the latter who is elevated by the contact but the white person who is dragged down and 'goes native' as they say here. In the same way, experience shows that such relationships do not improve the race but cause it to deteriorate. ${ }^{62}$

Segregation was also advanced by three notorious native ordinances of 1907 - the Control Ordinance, the Pass Ordinance, and the Master and Servant Ordinance - which together established a racist interventionist State within a legal framework. Jurgen Zimmerer notes that such a "policy of total control over the natives was at the very heart of German colonial rule from the very first consideration of how working relationships should be regulated as early as 1894." $" 63$

However, the exclusionist approach of the German colonial administration to the natives of South West Africa was demonstrated with utmost brutality in the events of the Herero genocide between 1904 and 1907; events that in many ways appears as the prelude to the Holocaust during WWII. The Herero war offered the colonial administration the excuse to exterminate the whole Herero community; the commander in chief and the man in charge of this campaign - Lieutenant-General Lothar von Trotha - was very close to the completion of this task when he was called back to Germany in the face of controversy in the metropolis over his policy. Nearly $80 \%$ of the Herero people, i.e. 60,000 Herero, were annihilated by the Germans during this campaign: some in battles, some deprived of food and water when driven to the desert by the colonial army and blocked there, and the rest in the inhuman condition of 'concentration camps' in the aftermath of the war. ${ }^{64}$ During that time, von Trotha is

\footnotetext{
Quoted in ibid., 21.
}

63 Ibid., 29.

64 For an account of the major causes behind the Herero war and the atrocity done by the German colonial army, see, JurgenZimmerer, "War, Concentration Camps and Genocide," in Genocide in German South West Africa, 41-60; Smith, German Colonial Empire, 60-65; Von Joeden-Forgey, "Nobody's People," 442. 
reported to have said that "the Herero people must leave the country. If they do not do so I shall force them with a big gun. Within the German frontiers every Herero, armed or unarmed, with or without cattle, will be shot dead. I shall take in no more women and children. I shall drive them back to their people or have them fired on." 65 The extermination order was finally lifted, but von Trotha's policy received endorsement when the German Chief of Staff von Schlieffen wrote to the Chancellor in the following words:

One can agree with him (von Trotha) in wishing to exterminate the whole nation or drive them out of the country [...]. The racial war which has flared up can only be brought to an end by the extermination or total subjugation of the one party. The latter option is however not feasible in the long term, judged on currently valid assessments. Therefore the objective of General von Trotha can be approved. But he just does not have the forces to carry it through. 66

It is due to this practical limitation alone that the Chief of Staff appealed for the lifting of the extermination order.

Such an endorsement of von Trotha's genocidal policy was not confined to the military establishments alone. In a fascinating article, Medardus Brehl exhibits how the literature of the time perceived the annihilation of the Herero and Nama as "a legitimate means of dealing with the inevitable and necessary confrontation of 'whites' and 'blacks', of 'civilised' and 'uncivilised'"; a phenomenon that can be explained through the nineteenth-century concepts of German entitlement, revolutionary culture, social Darwinism, and historiography. ${ }^{67}$ Brehl demonstrates that besides the publications that came from a closed circle of a particular social interest group, mainstream authors with immense popularity among mass people, in fact portrayed the events in ethno-nationalist terms. Among the many authors that Brehl's research reveals, the novel by Gustav Frenssen, entitled Peter Moors Fahrtnach Sudwest. Ein Feldzugsbericht (Peter

65 Quoted in Zimmerer, "War, Concentration Camps and Genocide," 48.

66 Quoted in ibid.,51.

67 MedardusBrehl, "The Drama was Played out on the Dark Stage of the Sandveldt: The Extermination of the Herero and Nama in German (popular) Literature," in Genocide in German South West Africa, 101. 
Moor's Journey to the South West. A Campaign Report), published in 1906 is of particular relevance given its Europe-wide reception. ${ }^{68}$ In his account of the South West African massacre, Frenssen portrays the incidents in purely nationalist terms, as a legitimate cause of ensuring German cultural homogeneity. For him, as Brehl notes, the extermination of the 'existential other' would not only suppress the threat posed to German culture, but would also allow men of diverse regional and social origins to create a homogeneous community. It is, therefore, legitimate as determined by evolutionary biology and the law of advanced cultural development, and hence, absolutely necessary. ${ }^{69}$ In the words of Frenssen, "these blacks deserve to die, before God and mankind, not because they murdered two hundred farmers and rose against us, but because they built no houses and dug no springs". 70

As far as international lawyers were concerned, Koskenniemi notes, they produced no critical accounts about the extremely brutal response of the German colonial administration towards native uprisings, for they considered this a natural consequence of Germany's emergence as a great colonial power. ${ }^{71}$ Dampierre argues that in the minds of German intellectuals, the notion of German racial superiority induced instincts of domination, and Germany's military might, then, relied on the idea of violence with moral comfort. ${ }^{72}$ This form of violent domination was unique, in that it differed from the intellectual domination of the Latin races, or commercial ambitions of the Roman and British empires, or from the species of religious mysticism of the Arabs, or the artistic mysticism of the Hellenes. ${ }^{73}$ Given that 'Germanism' was a civilisation deeply rooted in a particular race, instead of being a universal civilisation that had the

68 Frenssen was an extremely popular writer in Germany; in fact, he was even put forward as a candidate for the Nobel Prize for literature in 1912. This book was a best-seller in Germany and abroad. It was translated into English, Danish, Dutch, Afrikaans, and Swedish. For a list of contemporary popular Geman literature on colonial war, see Brehl, 104.

Ibid.,106.

Quoted in ibid.

11 Koskenniemi, 167.

72 Dampierre, German Imperialism and International Law, 43.

73 Ibid., 43. 
potential of accommodating other races, Dampierre asserts that the German imperialism was a force for elimination in contrast to that of the Hellenes, the Romans, the Arabs, the British, and the French, which had been in each case a force for assimilation; it is this original and dangerous characteristic that differentiated German imperialism from the rest of the civilised world. ${ }^{74}$ And Dampierre has put this in the following words:

In fact, from the moment that the German becomes possessed with the idea of an innate superiority whether historic, providential or biological imposing on his race the obligation to civilise the world, his conception of the relative rights of nations must undergo a profound modification, the duty of expansion by means of elimination which this mission imposes being scarcely reconcilable with the right to exist of other nations. ${ }^{75}$

With this analogy, it was, therefore, natural that Imperial Germany would adopt brutal means in warfare in order to execute the 'sacred' task of elimination. ${ }^{76}$

Nevertheless, in the political circle of the metropolis, information on the South West African atrocities created controversy over German colonial policy. Since the very beginning, colonialism had been a fertile source of political manoeuvring for almost all political philosophies. According to Smith, participants in the German political system employed colonialism as a tool to get what they wanted and as a means of overcoming some of the major deficiencies in the system the government in particular was vulnerable to attack and criticism during the annual budget review by the Reichstag and Budget Commission. ${ }^{77}$ Following the reports of genocide of the Herero and Nama peoples, the Social Democratic Party (SDP) refused any further backing for the colonial war that initially led to the rejection of part of the supplementary budget submitted by the Government to pay for the

74 Ibid., 43-44. In the following section, we shall examine the liberal, assimilationist thrust of French colonialism and its subsequent adjustment with the notion of 'association' in face of pragmatic needs.

75 Ibid., 46. Cf. Anthony Carty, "The Evolution of International Legal Scholarship in Germany during the Kaiserreich and the Weimarer Republic (1871-1933)," German Yearbook of International Law 50 (2007), 29-90.

76 Dampierre, 134-135.

77 Smith, German Colonial Empire, 122. 
continuation of the colonial war in South West Africa, and finally, to the dissolution of the parliament. ${ }^{78}$ Paradoxically, in the elections to the Reichstag at the beginning of 1907 that followed the dissolution, nationalist campaigns depicted the SDP and the Centre Party as "enemies of colonialism, opposed to the national interest and traitors to the fatherland." 79 This along with other elements of electionengineering offered the conservative block a majority in the Reichstag. Heyden notes that the election result had an 'educational influence' on German social democracy, in that it finally led to the development of concepts of 'socialist colonialist policies' in which colonies came to be perceived as an economic necessity and in the public interest of the German Reich. ${ }^{80}$

Another less-complicated response in the metropolis towards German atrocities in the colonies was outright denial of any guilt on the grounds that such measures were either necessary or deviations of law that were punished; the strongest justification relied on the similar or even worse treatment of the natives by other European colonial Powers. An archetypical example of such a stance is the works of Heinrich Schnee, a lawyer, former colonial Governor, and a member of the Reichstag. In the context of Germany's loss of colonies following the Great War, Schnee wrote: "the natives, satisfied, and more than satisfied, with German sovereignty, desired nothing better than its continuance." ${ }^{81}$ Under the chapter-title "What the Natives Really Want', he claimed that "[i]f a genuine, uninfluenced, and impartial plebiscite could be taken, Germany would need to have no fear as to the result of the native vote. $" 82$ Throughout his writings, one can hardly ignore the racial foundations of his arguments. A similar approach was taken by Matthias Erzberger who held the view that although Germany had made mistakes in her colonial policy, such

78 Ulrich van der Heyden, "The 'Hottentot Elections' of 1907," in Genocide in German South West Africa, 114.

79 Ibid., 116.

80 Ibid., 117-118.

81 Heinrich Schnee, German Colonisation: Past and Future (London: George Allen \&Unwin Ltd., 1926), 169.

82 Ibid., 171. 
mistakes were not greater than those of other colonial Powers. ${ }^{83}$ For him, colonialism was a matter of national pride as well as an indication of superiority; thus, in the aftermath of Germany's defeat in the Great War, he declared that "Germany cannot, for the sake of her honour, submit to be shut out from the ranks of the colonising Powers. If she were struck out of the ranks of colonising nations, it would mean the moral degradation of Germany, and she would, from the cultural point of view, be inferior to countries like Portugal." 84

\section{The Ethnic 'Otherness' Reflects Back on the Understanding of the 'Self'}

While Germany's polygenic, exclusionist self-image was reflected in its extreme brutal extermination of the natives of South West Africa, in the metropolis the exclusion of the native 'other' on racial grounds took place through 'distancing'. The late nineteenth-century German colonial enthusiasts, such as Carl Hagenbeck, Felix von Luschan, and Hilke Thode-Arora, had recourse to the idea of 'colonial exhibitions' (Völkerschauen) to highlight the distinctiveness of the natives, as well as to educate the Germans about the practicalities of the science of race. In one such exhibition in Hagenbeck's Tierpark, clusters of authentic villages representing the cultures were built on either side of a path; they were numbered, labelled, and crossreferenced in an educational brochure. ${ }^{85}$ To sharpen the line of difference between the native show-members and the European visitors, whose mutual communication was restricted, the arrangement in the Tierpark and Berlin's Zoological Garden allowed the visitors, as von Joeden-Forgey notes, "to move from one display of people to the display of animals without leaving the grounds, a geographical fact that suggested a greater link between non-Western peoples and animals than between non-Western and Western peoples." 86 In 1896, the German State itself organised one of the largest colonial

\footnotetext{
83 Matthias Erzberger, The League of Nations: The Way to World's Peace, trans. Bernard Miall (NY: Henry Holt and Company, 1919), 242. 
exhibitions in Berlin's Treptower Park to create the appearance of vast cultural and racial differences between Germans and colonial subjects. ${ }^{87}$

Such a polygenic notion of racial segregation, and the proposition that "colonial governance was principally a matter of solving the "race problem' was enough of a consensus issue by 1910". ${ }^{88}$ One good example is African linguist Carl Meinhof, who despite his cosmopolitan image shared with the conservatives the aversion to racial mixing. While, given his background in Protestant theology and his work with Protestant missions, he kept relying on the monogenic idea behind the 'civilising mission,' he firmly opposed any idea of racial mixing, especially in relation to the natives. ${ }^{89}$ Meinhof even expressed concerns about Africans visiting, residing, and being educated in Germany, for in his view no African could ever be a true German. ${ }^{90}$

This then was a moment of understanding the ethnic 'self' through its relationship with the ethnic 'other'. Proponents of political racialism believed that colonial governance had taught the German State

'that 'mixing' was a threat to national wellbeing, that race differences was a radical phenomenon involving completely opposing cosmic spaces, and that humanity (humanitarianism) must be exercised in conformity with racism's scientific laws". 91

With the conviction that a colonial model of racially exclusionist governance in the metropolis would secure Germany's cosmic

87 Ibid., 388. Interestingly enough, even in June 2005 an African cultural festival, entitled 'African Village', took place in the local zoo of the town of Augsburg in Southern Bavaria as the zoo provided, according to the brochure of the event, the 'natural environment' to demonstrate the 'dark continent' in a 'genuine exotic ambience'. This exposition of racism and cultural insensitivity created controversy in Germany. See Charles Hawley, "African Village Accused of Putting Humans on Display," Spiegel Online, June 9, 2005; available at <http://service.spiegel.de/cache/international/0,1518,359799,00.html>.

88 Von Joeden-Forgey, "Nobody's People," 382.

89 Ibid., 417.

90 Carl Meinhof, DeutschlandsPflichten in Afrika (Hamburg: DeutschEvangelischenLaien-Missions-Bund, 1912), 12, cited in ibid., 417.

91 Von Joeden-Forgey, "Nobody's People," 432. 
superiority, leading proponents such as Josef Reimer, Klaus Wagner, and Heinrich Class juxtaposed colonial scenarios with the Eastern expansion in which the non-Aryan 'other' was excluded from the Germanic image of the 'self' in the pattern of colonial brutalities. ${ }^{92}$

The liberal vision of universalism came under strong criticism here. Reimer found the notion of universal humanity as a 'bastard-idea' introduced by the 'bastards of Roman Empire', and if the Germanic race got engaged in it, according to him, alien races "would be able to 'smuggle' themselves into the German body politic by virtue of the political openness fostered by false ideas of humanity". ${ }^{93} \mathrm{He}$ therefore hoped that the proper understanding of humanity in racial terms would awaken the German youth to the new possibilities as well as necessities of their time: the German State had to expand, and at the same time a strict separation of the races had to take place in the occupied territories as well as at home - 'civitas Germanica' wherein persons with only Germanic blood would be incorporated and given equal rights. ${ }^{94}$ Similarly, Wanger described the whole idea of common humanity of a raceless world as "volk-adverse and therefore nature-adverse and therefore also culture-adverse". 95

Thus, on the one hand, the notion of the ethnic German 'self' is reflected in its relationship with the native 'other' as expressed in the campaign for settlement colonies, and on the other, its polygenic exclusionist framework of dealing with the 'other' then reflected back on the image of the 'self' to make it even more racist, hence, exclusionist as the Nazi regime later demonstrated. In this sense, the nineteenth-century German understanding and actual execution of colonial policies sharply contrasted with the liberal vision of civilising the colonial 'other' through assimilation. As Meinhof asserted, German and French cultures were different in that Germans could not adopt 'foreign ways' without becoming a false people; this reflects

92 See Leon Poliakov, The Aryan Myth: A History of Racist and Nationalistic Ideas in Europe (NY: Barnes and Noble, 1996), 301-304.

93 Josef Reimer, EinPangermanisches Deutschland (Berlin and Leipzig: Friedrich Luckhardt, 1905), 268, cited in von Joeden-Forgey, 438.

94 Reimer, EinPangermanisches Deutschland, 130, cited in von Joeden-Forgey, 440.

95 Klaus Wanger, Krieg (Jena: Costenoble, 1906), 67-68, cited in von JoedenForgey, 438-439. 
both "the long-standing Romantic critique of the French universalism" as well as "a more recent German colonial reformist critique of the supposedly assimilationist thrust of many French colonial policies". ${ }^{96}$

\section{Conclusion}

What I emphasise in the foregoing brief sketch of German colonial policies is that the nineteenth-century colonial projects not only demonstrated an ethnic dichotomy of the European 'self' and the nonEuropean 'other', but also explained how this dichotomous relationship reflected the image of the 'self' on the 'other' and in return, this interaction with the 'other' was then reflected back in the dynamic process of constructing the 'self'. I also demonstrate how nineteenth-century international law played its part in this complex process by reflecting its understanding of the 'self' in legal terms - the State - in the legal response to the colonial 'other' and the colonial project as a whole.

However, the whole notion of the European 'self' was drastically shaken with the force of nationalism reaching its peak on the eve of the Great War. The ethnic discourse on self and other came to shape the interwar international law, in relation to the protection of the leftouts and the minorities in the process of crafting the national selfimage in Eastern and Central European States in conservative sense. The very foundation of this interwar mechanism relied on how the liberal West portrayed the ethnic non-Western 'other' within Europe in contrast to its own image of the 'self' - a pattern that reappeared in the post-Cold War European mechanisms of minority protection. In this sense, international law, developed through the nineteenth century discourse on the liberal and conservative streams of identity formation, demonstrates the ethnic dichotomy of 'self' and 'other' even in its present-day use.

96 Carl Meinhof, "Suittlichkeit und Kreig," Vortragegehlatenim Hamburger Volksheim, Nr. 10, 1914, cited in von Joeden-Forgey, 427. 